\title{
MULTI-CRITERIA APPROACH IN EVALUATING CONTRIBUTION OF SOCIAL ENTREPRENEURSHIP TO THE EMPLOYMENT OF SOCIALLY-EXCLUDED GROUPS
}

\author{
Marija DŽUNIĆ, Jelena STANKOVIĆ, Vesna JANKOVIĆ-MILIĆ \\ Faculty of Economics, University of Niš, Trg kralja Aleksandra Ujedinitelja 11, 18000 Niš, Serbia
}

Received 01 February 2016; accepted 25 June 2017

\begin{abstract}
The paper explores the potential impact of social enterprises on social exclusion. In particular, the role of social enterprises in labour market integration of socially excluded individuals is analysed within the existing theoretical and policy discourses of exclusion. Taking into account the difficulties in measuring the social impact of social enterprises, our study contributes to the quantitative literature on the performance of social enterprises, taking the number of integrated people as a measure of the impact on social exclusion. The research is based on data on the employment of marginalized groups, derived from a unique dataset collected by a recently conducted survey of social enterprises in Serbia. The original methodological framework combines statistical methods and multi-criteria decision making model, in order to evaluate the contribution of different types of enterprises to the employment of excluded individuals. Weights determination for the MCDM model is performed using entropy while TOPSIS method is applied for the ranking of the types of social enterprises according to the employment of socially excluded categories. The results indicate that enterprises for employment of persons with disabilities, citizens' associations and cooperatives in Serbia contribute the most in integrating the socially excluded.
\end{abstract}

Keywords: social exclusion, social enterprises, work integration, multi-criteria decision making, entropy, TOPSIS.

JEL Classification: D63, I31, C44.

\section{Introduction}

The concept of social entrepreneurship has received an increasing interest both in theory and policy, since it first appeared at the late XX century (Defourny, Nyssens 2010). Most of its prominence originates from the engagement of social enterprises in resolving the problems of unemployment, poverty and social marginalization, thereby creating social value (Alvord et al. 2004; Mair, Marti 2006). For this reason, social enterprises have been given a label of innovative and creative solution to a number of social problems, filling the gap left by inefficient state policies (Nicholls 2006). However, the research literature raises serious concerns

${ }^{\star}$ Corresponding author. E-mail: marija_dzunic@ni.ac.rs

This is an Open Access article distributed under the terms of the Creative Commons Attribution License (http://creativecommons. org/licenses/by/4.0/), which permits unrestricted use, distribution, and reproduction in any medium, provided the original author and source are credited. 
related to the power of social enterprises in combating different aspects of social exclusion (Amin 2009; Toner et al. 2008). This paper aims to contribute to the existing debate on the potential impact of social enterprises on exclusion. The role of social enterprises is examined within the existing theoretical and policy discourses of social exclusion.

Our study focuses on a specific type of social enterprises designed to provide work integration of disadvantaged unemployed people, who are at risk of permanent exclusion from the labor market (Spear, Bidet 2005). The paper builds on the literature that examines the potential of social enterprises in supporting the excluded to reintegrate into society. Although there is a vast amount of empirical research on the subject, it is mostly based on qualitative metrics and case study approaches. Quantitative research on the performance of social enterprises in supporting socially excluded individuals is limited, mostly because of the lack of empirical data (Short et al. 2009; Doherty et al. 2014). Another problem is related to the measurement of the impact of social enterprises, since various indicators can be used for the evaluation of their performance (Dussart et al. 2003; Maree 2005; Lee et al. 2014). This study contributes to the research on the evaluation of work integration social enterprises, based on the number of employed marginalized people. Data on the employment of marginalized groups is derived from a unique dataset collected by a recently conducted survey of social enterprises in Serbia. The original methodological framework combines statistical methods and multi-criteria decision making model.

This paper begins with a review of literature that examines two key concepts of the research: social exclusion and social enterprises. Following on from this, the role of the social enterprises in integrating the socially excluded into the labour market is examined in particular. In addition, the problems of evaluating the social impact of social enterprises are considered. The paper then reports on the quantitative research that investigated which types of social enterprises in Serbia employ the largest shares of socially excluded categories. Finally, the research results are discussed and some concluding remarks and policy implications are offered.

\section{Literature review}

In this section, we elaborate on different conceptions of social exclusion and interpretations of social entrepreneurship. After exploring these key concepts, we go on to consider the role of social enterprises within the social exclusion theory and policy and examine the potential impact of social entrepreneurship on exclusion. The concept of social exclusion has been increasingly used to denote multiple social problems and various disadvantaged positions, gaining relevance both in theoretical and political discourses (Levitas 2004; Gilbert 2002; Giddens 1998). The term itself originates from France and was first used to label the individuals not covered by the social protection system who therefore represent the source of social problems (Lenoir 1974). During the 1980's, social exclusion has been defined within the framework of poverty and inequality. Later on, the concept has been redefined to incorporate exclusion from the labour market rather than poverty (Burchardt et al. 2002). This has caused a shift from European redistributive social policy discourse towards the US libertarian tradition that accentuated paid employment as a means for fighting social exclusion (Toner et al. 2008), instead of dependence of the excluded on the welfare safety net. Taking 
into account these developments, three distinct discourses are recognized in the literature on social exclusion (Silver 1994; Levitas 2004; Seyfang 2004). Redistributionist discourse considers exclusion as a disadvantage caused by poverty and multiple deprivation processes. This line of research accentuates that exclusion is a consequence of external factors (Toner et al. 2008), which gives rise to the redistributive intervention of the state. Within the demarcation of strong vs weak version of exclusion (Byrne 2005), this discourse would fall under the strong version, implicating that exclusion is the result of the structural processes of the wider society, that allow the deepening of inequality between social groups. Within this view, society is pictured as a ladder (Koller, Davidson 2008), where owing to unequal distribution, those at the top of the ladder acquire the most of social resources and power, compared to the social groups that occupy the bottom of the ladder (Kummitha 2016). The second, social integrationist discourse emphasizes labour market participation as a means for fighting exclusion (Cochrane 2003; Seyfang 2004). This is a weak comprehension of exclusion (Levander 2009), perceiving individuals as active agents of their condition and focusing on enhancing their possibilities to be included in the society, primarily through paid employment (Lister 2004). Unlike the ladder metaphor, the weak version of social exclusion depicts the society as bounded space, implicating that individuals can be either inside (included) or outside the bounds - socially excluded (Koller, Davidson 2008). Finally, the moral underclass discourse defines social exclusion as a consequence of deviance from moral norms, rather than the result of overall inequalities (Toner et al. 2008; Levander 2009).

Social exclusion can generally be comprehended as a multidimensional process, since individuals can be excluded along one or more dimensions. Exclusion from the labour market, with the resulting unemployment, lack of income and poverty, is the cause of other forms of exclusion (Iwacewicz-Orlowska 2016): poor housing, low educational attainment, limited access to health services and other public goods. Socially excluded are also denied possibilities to participate in political processes and integrate in social activities, which is often described as diminishing social capital (Putnam 1993). Taking into account multiple dimensions of social exclusion, it can generally be defined in the following terms: individuals are socially excluded if they do not participate in key activities of the society in which they live (Burchardt et al. 2002). On the other hand, the inclusion of individuals in the society requires participation in all dimensions. Furthermore, different mechanisms, motivations and agents produce social exclusion and inclusion (Silver 2010), so it is not sufficient only to bring the excluded individuals back into the mainstream. A necessary precondition is to equalize the status quo, neutralize the exclusionary forces in the society and then offer assistance for the inclusion in society activities. In other words, social exclusion as a multi-faceted phenomenon, requires a "holistic" approach in the reintegration of the excluded into society (McNeill, Weaver 2010).

The arising problems of social exclusion, deprivation and poverty during the 1970's, have made ground for the appearance of social enterprises as new breed of organizations that would fill the gap left by inefficient state policies for protecting and re-integrating the socially excluded (Nicholls 2006). In a number of European countries, the persistence of high unemployment levels, accompanied with the need to reduce state budget deficits and transform integration policies has led to the appearance of new entrepreneurial dynamics within the third sector (Defourny, Nyssens 2010). The problems of social exclusion have ceased to be 
exclusively the concern of state institutions, so that social enterprises emerged as a part of the welfare state transformation (Haugh, Kitson 2007). Adhering to the social integrationist discourse of exclusion, social enterprises engage in the empowerment of excluded individuals, enhancing their prospects for inclusion and removing them from welfare dependency (Austin et al. 2006; Seyfang 2004).

There has been an increasing interest both in theory and policy for the notion of social enterprise, since it first appeared in 1990's. Despite abundant theoretical literature, there is no unique definition of the concept, since this field is divided among different schools of thought (Short et al. 2009; Dacin et al. 2010; Hill et al. 2010). Owing to different contexts and backgrounds, two social entrepreneurship traditions dominate in the field, originating from US and Western Europe (Kerlin 2006; Bacq, Janssen 2011). Within the US literature, two social entrepreneurship schools can be identified (Dees, Anderson 2006): the social enterprise school, stressing entrepreneurial nature, market orientation and income generation activities of social enterprises that conduct social activities (Weerawardena, Mort 2006); and social innovation school, accentuating the innovative practices of entrepreneurs in tackling social needs, irrespective of the organizational form (Dees 1998). On the other side, the European literature stresses the social objectives of third sector organizations that have emerged as a reaction to the retreat of the state from welfare services (Kerlin 2006). The UK approach (Department of Trade and Industry 2002) defines social enterprises as business with primarily social objectives, not driven by the urge to maximize profit for the owners and stakeholders, but reinvesting surplus for the purpose of realizing social objectives. European research on social enterprises is largely conducted by the European research network for social economy (The Emergence of Social Enterprise in Europe - EMES), that was founded in 1996, consisting of scholars that cooperate on research of social enterprises in EU, taking into account national differences between EU countries. According to the common approach to studying social entrepreneurship built within the EMES network, social enterprises are defined as "organizations with an explicit aim to benefit the community, initiated by a group of citizens and in which the material interest of capital investors is subject to limits. Social enterprises also place a high value on their autonomy and on economic risk-taking related to ongoing socio-economic activity." (Defourny, Nyssens 2006). This definition serves as a tool for determining an ideal type of social enterprise, thereby enabling researchers to locate specific organizations among the social entrepreneurship framework.

Based on different conceptualizations and competing definitions, social enterprise can generally be considered as a contested concept (Choi, Majumdar 2014), since different schools express contesting views upon numerous issues: income generation, profit distribution, legal forms, the link between the social mission of the enterprise and goods and services it provides, the role of individual entrepreneur, the importance of innovation and the structure of governance (Hoogendoorn et al. 2010). However, there seems to be an agreement that the core defining feature of social enterprises is their social mission - creating social value, producing social impact or addressing social needs (Dees 1998; Mair, Marti 2006; Weerawardena, Mort 2006). Social enterprises are often confronted against the double bottom line (tension between social and economic goals) since they often pursue financial goals, in order to provide funding for performing their social mission (Evers 2001; Peredo, McLean 2006; Austin et al. 2006). 
Social enterprises address a large number of social problems, such as social care, environmental protection, local development, urban regeneration, health and child care services, etc. A major field within the social entrepreneurship is occupied by work integration social enterprises (WISEs), designed to target the specific form of exclusion, related to labor market participation (Defourny, Nyssens 2006; Hulgård, Bisballe 2008; Davister et al. 2004; Spear, Bidet 2005). The main aim of WISEs is to help individuals threatened by permanent exclusion from the labor market, by integrating them into work and society, through productive activity (Defourny, Nysssens 2006, 2010). They provide skills enhancement and facilitate employment of targeted disadvantaged groups, unable to attain employment on orthodox labor markets (people with disabilities, low-skilled workers, elderly, women, etc.). There is more than one type of WISE, offering various models of integration to the excluded (Davister et al. 2004): enterprises offering permanent occupational integration (sheltered workshops, work care centers); WISEs that provide permanent, self-subsidized employment (community businesses, social firms); enterprises that re-socialize the excluded through productive activity (social cooperatives, sheltered employment centers); and initiatives offering transitional employment or training. This is consistent with the findings that different forms of social enterprises impact exclusion in different ways (Teasdale 2008).

There is an active debate on the impact of social enterprises on social exclusion. There is evidence that social enterprises successfully integrate the socially excluded into the labor market (Smallbone et al. 2001; Aiken 2006). According to Hudson (2005), social economy has the potential of creating new possibilities and forms of employment. In the assessment of the impact of social enterprises on the employment of disadvantaged groups, Haugh and Kitson (2007) claim that by providing employment opportunities, training or mentoring, social enterprises help increase the demand for marginalized labor. Country analyses of the performance of European WISEs in integrating the excluded into the labor market and the society confirm their contribution to the improvement of the skills and abilities of disadvantaged workers and their social integration (Alvord et al. 2004; Vidal 2005; Spear, Bidet 2005; Borzaga, Loss 2006; Perista, Nogueira 2006; Defourny, Nyssens 2008). On the other hand, there are serious concerns whether social enterprises can be efficient in integrating the excluded into the society (Aiken 2007; Amin 2009; Blackburn, Ram 2006), although it is emphasized that successful transitions are possible, if the enterprise is able to offer paid employment. Toner et al. (2008) conclude that social enterprises can make an impact on social exclusion, but cannot change the conditions that cause deprivation and exclusion.

Building on this debate, a question of measuring the social impact of social enterprises has been raised, indicating the complexity of such evaluation, which originates from the competing missions of social enterprises (Nicholls 2005; McLoughlin et al. 2009; Lane, Casile 2011). The vast amount of research is based on qualitative metrics and case study analysis, while quantitative studies have not been very abundant, mostly due to absence of a unique measure for the evaluation of their performance or the lack of empirical data (Short et al. 2009; Doherty et al. 2014). Our study aims to contribute to the quantitative literature on the performance of social enterprises, taking the number of integrated people as a measure of the impact on social exclusion (Simon 1998). Taking into account the variety of types of work integration social enterprises (Davister et al. 2004), we attempt to evaluate the contribution of different types of enterprises on the employment of excluded individuals. 


\section{Data sources and research methodology}

The research in this paper is based on a unique base of micro data provided by Statistical Office of the Republic of Serbia (SORS 2014). The database has been created as a result of the project called Economic Impact of Social Enterprises, financed by European Commission and carried out by The Statistical Office of the Republic of Serbia in cooperation with the Group for Development Initiative SeConS and non-governmental organization Group 484 (SORS 2014a). This project is a part of EU Social Business Initiative that is aimed at promoting research on social enterprises, by enhancing their institutional visibility and raising awareness of their importance (EU Commission 2011). The project resulted in collecting reliable and comparable data on goods and services produced by social enterprises, employment and capital investments within this sector. The data collection is based on full coverage of enterprises in Serbia that meet the criteria for belonging to social enterprises sector (where $87.8 \%$ of reporting units answered the questionnaire) and was conducted in 2013. The analysis in the paper is based on the sample consisting of 1180 social enterprises, with a total of 10189 employees. For the purpose of research in this paper, we have used the data on the number of employees in social enterprises that belong to various categories of socially excluded.

The typology of social enterprises in the sample is based on the above elaborated EMES definition of social enterprise as a collective entrepreneurial unit that operates within social economy (Defourny, Nyssens 2006). An ideal type of social enterprise, according to EMES network approach, is defined through three sets of indicators, which reflect three distinct dimensions of social enterprises - economic, social and participatory governance (Defourny, Nyssens 2012). The enterprises included in the sample are selected based on whether they meet a number of economic and social criteria. Economic criteria include: engaging in continuous productive activities; assuming significant level of economic risk; requiring minimum amount of paid work. Social criteria relate to: having an explicit aim to benefit the community; limited profit distribution and participatory and democratic decision-making principles. The sample includes: (1) development agencies; (2) foundations; (3) business incubators; (4) enterprises for employment of people with disabilities; (5) citizens' associations and (6) cooperatives. Enterprises that do not meet the EMES criteria, such as traditional civic associations or profit oriented agricultural cooperatives are excluded from the sample.

The methodology applied in the paper consists of several steps. First, descriptive statistics is applied in order to present the structure of the sample. Then, multi-criteria decision making model is developed, with the aim to rank different types of social enterprises based on the criteria of contribution to the employment of socially excluded groups. The relevant criteria included in the model are the relative shares of employed categories that are at risk of social exclusion and more difficult to employ: young people, older people, women, people without professional qualifications, employees with elementary education and employees that belong to vulnerable groups. The alternatives in the model are types of social enterprises in Serbia.

Among a wide range of methods for ranking of alternatives, (AHP, ELECTRE, VIKOR, etc.), for this research TOPSIS has been applied, as an easy to understand and very popular method. It has the same number of steps regardless of the problem size. TOPSIS can identify the best alternative quickly (Jee, Kang 2000; Yong 2006; Shih et al. 2007). Both TOPSIS and AHP are good at addressing rank reversal issue which is exactly the limitation of ELECTRE method (Zanakis et al. 1998). Moreover, TOPSIS and AHP have a very simple process, 
whereas ELECTRE process can be more complicated to understand or to explain its outcome. ELECTRE combines distance measures and weights in a different way compared to TOPSIS which is based on generating weights (Parkan, Wu 1997; Roy 1968). Comparing to AHP, TOPSIS behaves differently depending on the number of criteria. For the number of criteria shown in our paper, TOPSIS is a better choice due to few criteria and therefore more rank reversals (Zanakis et al. 1998; Saaty 1977). When we compare VIKOR to TOPSIS, we first notice that they use different kinds of normalization. Unlike the VIKOR method which uses linear normalization, TOPSIS uses vector normalization which means they introduce different aggregating functions for ranking (Jati 2012; Opricovic, Tzeng 2004). We decided to apply the TOPSIS method because it chooses the alternative which has the shortest distance from the ideal solution or the longest distance from the negative-ideal solution. Considering all these reasons, we decided that the best MCDM method for our research is the TOPSIS method.

Based on the discussion above, a flowchart for the methodology applied in this paper is presented in Figure 1.

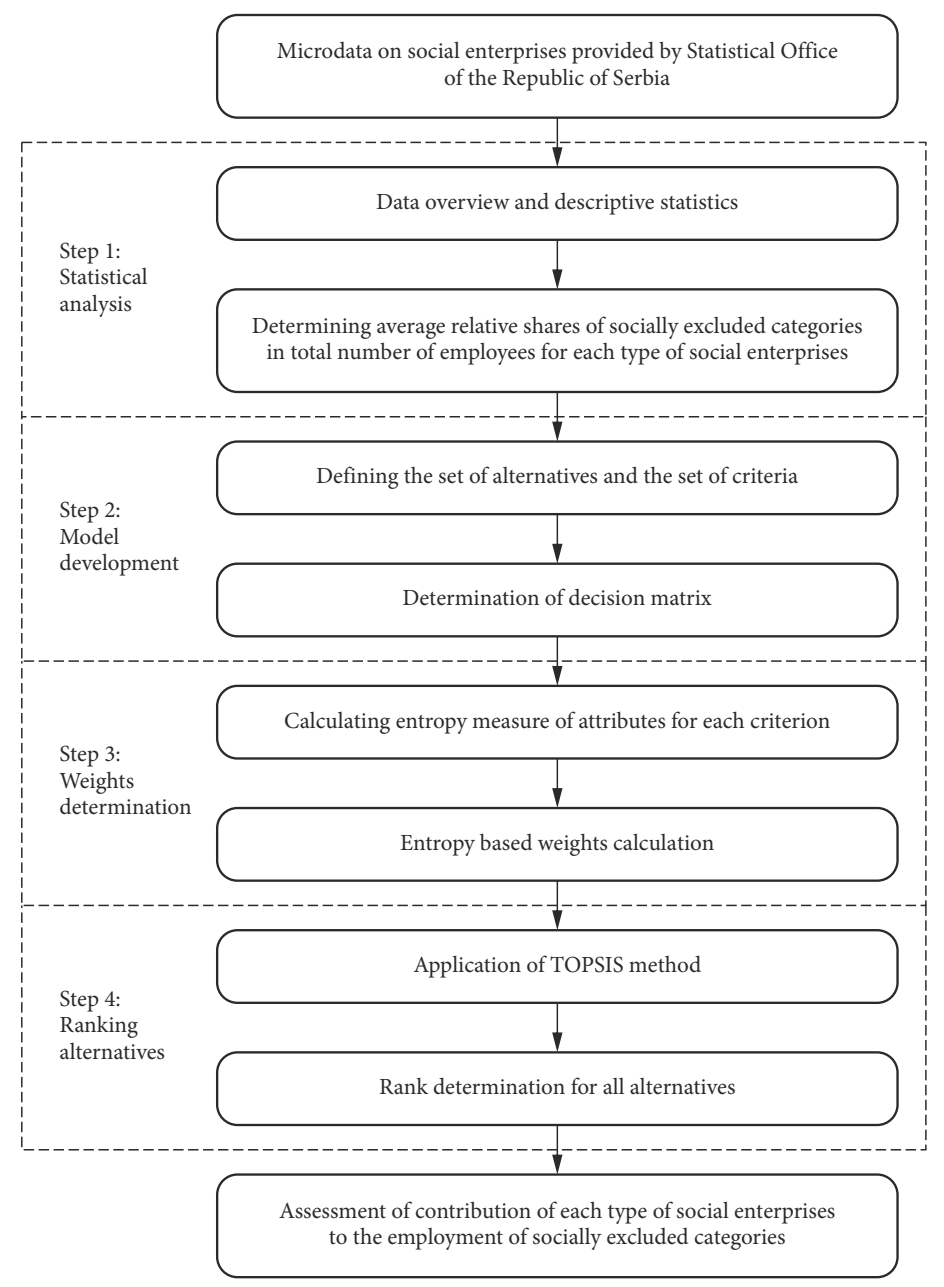

Figure 1. Methodology flowchart 


\section{Descriptive statistics and data overview}

Social enterprises in the sample employ around $0.6 \%$ of the total number of employed labour force in Serbia (SORS 2014a). This implies that the aggregate impact of social entrepreneurship on employment is limited at best. Serbian labour market is characterized by persistently high unemployment rates, youth unemployment and large employment in informal economy, while $41.3 \%$ of the population is at risk of poverty or social exclusion (EU SILC 2016). The position of marginalized groups is particularly unfavourable (Radović-Marković 2016). Social enterprises in Serbia have developed in the course of the transformation of the welfare system (Vuković 2013), owing to civic society's efforts to fill the gaps left by the public welfare institutions.

Therefore, the paper focuses on the potentials of different types of social enterprises in Serbia for work integration of social categories that belong to population more difficult to employ, and therefore exposed to the risk of social exclusion. For the purpose of the analysis, several social categories have been selected: the young (aged under 30), the elderly (aged over 60), individuals with no qualifications, individuals with low educational attainment, women and members of different vulnerable categories $\left.{ }^{1}\right)$. Enterprises in the sample employ 1693 employees that belong to vulnerable groups ( $16.6 \%$ of total employment in the sector) and a significant share of individuals with low education (employees with no qualifications and primary education account for $24.9 \%$ of total employment in social enterprises). The structure of the sample according to the type of social enterprise and the employed categories is presented in Table 1.

Table 1. Cross-tabulation between types of social enterprises and employed categories (source: Authors' preview based on SORS 2014)

\begin{tabular}{|c|c|c|c|c|c|c|}
\hline & $\begin{array}{l}\text { The } \\
\text { Young }\end{array}$ & Elderly & Woman & $\begin{array}{c}\text { Without } \\
\text { professional } \\
\text { qualifications }\end{array}$ & $\begin{array}{l}\text { With } \\
\text { elementary } \\
\text { education }\end{array}$ & $\begin{array}{c}\text { Vulnerable } \\
\text { groups }\end{array}$ \\
\hline $\begin{array}{l}\text { Development } \\
\text { agencies }\end{array}$ & $\begin{array}{c}68 \\
(4.66 \%)\end{array}$ & $\begin{array}{c}11 \\
(1.61 \%)\end{array}$ & $\begin{array}{c}179 \\
(4.67 \%)\end{array}$ & $\begin{array}{c}0 \\
(0 \%)\end{array}$ & $\begin{array}{c}14 \\
(0.71 \%)\end{array}$ & $\begin{array}{c}2 \\
(0.12 \%)\end{array}$ \\
\hline Foundations & $\begin{array}{c}124 \\
(8.50 \%) \\
\end{array}$ & $\begin{array}{c}9 \\
(1.32 \%) \\
\end{array}$ & $\begin{array}{c}111 \\
(2.89 \%) \\
\end{array}$ & $\begin{array}{c}0 \\
(0 \%) \\
\end{array}$ & $\begin{array}{c}4 \\
(0.20 \%) \\
\end{array}$ & $\begin{array}{c}5 \\
(0.30 \%) \\
\end{array}$ \\
\hline $\begin{array}{l}\text { Business } \\
\text { incubators }\end{array}$ & $\begin{array}{c}4 \\
(0.27 \%)\end{array}$ & $\begin{array}{c}2 \\
(0.29 \%)\end{array}$ & $\begin{array}{c}30 \\
(0.78 \%)\end{array}$ & $\begin{array}{c}0 \\
(0 \%)\end{array}$ & $\begin{array}{c}1 \\
(0.05 \%)\end{array}$ & $\begin{array}{c}1 \\
(0.06 \%)\end{array}$ \\
\hline $\begin{array}{l}\text { Enterprises } \\
\text { for employment } \\
\text { of people } \\
\text { with disabilities }\end{array}$ & $\begin{array}{c}279 \\
(19.12 \%)\end{array}$ & $\begin{array}{c}40 \\
(5.87 \%)\end{array}$ & $\begin{array}{c}877 \\
(22.86 \%)\end{array}$ & $\begin{array}{c}155 \\
(27.29 \%)\end{array}$ & $\begin{array}{c}486 \\
(24.68 \%)\end{array}$ & $\begin{array}{c}1293 \\
(76.37 \%)\end{array}$ \\
\hline $\begin{array}{l}\text { Citizens' } \\
\text { associations }\end{array}$ & $\begin{array}{c}195 \\
(13.37 \%)\end{array}$ & $\begin{array}{c}340 \\
(49.85 \%)\end{array}$ & $\begin{array}{c}705 \\
(18.37 \%)\end{array}$ & $\begin{array}{c}15 \\
(2.15 \%)\end{array}$ & $\begin{array}{c}137 \\
(6.96 \%)\end{array}$ & $\begin{array}{c}228 \\
(13.47 \%)\end{array}$ \\
\hline Cooperatives & $\begin{array}{c}789 \\
(54.08 \%)\end{array}$ & $\begin{array}{c}280 \\
(41.06 \%)\end{array}$ & $\begin{array}{c}1935 \\
(50.43 \%)\end{array}$ & $\begin{array}{c}398 \\
(70.07 \%)\end{array}$ & $\begin{array}{c}1327 \\
(67.39 \%)\end{array}$ & $\begin{array}{c}164 \\
(9.69 \%)\end{array}$ \\
\hline Total & $\begin{array}{c}1459 \\
(100 \%)\end{array}$ & $\begin{array}{c}682 \\
(100 \%)\end{array}$ & $\begin{array}{c}3837 \\
(100 \%)\end{array}$ & $\begin{array}{c}568 \\
(100 \%)\end{array}$ & $\begin{array}{c}1969 \\
(100 \%)\end{array}$ & $\begin{array}{c}1693 \\
(100 \%)\end{array}$ \\
\hline
\end{tabular}

\footnotetext{
${ }^{1}$ Vulnerable categories include people with disabilities, refugees and IDPs, ethnic minorities, victims of violence, single parents, people with no education, persons aged over 50 that have been laid off, etc.
} 
The structure of employed categories in different types of social enterprises indicates that the largest share of young people employed in this sector (54\%) is employed in cooperatives. This type of social enterprise also employs the largest share of women (50.43\%), people without professional qualifications $(70.07 \%)$ and people with elementary education $(67.39 \%)$. Out of the total number of elderly employees in the social enterprise sector, $49.85 \%$ work in citizens' associations. As expected, members of vulnerable groups have found their refuge in the enterprises for employment of people with disabilities $(76.37 \%)$, while the second largest employer of this social group are the citizen associations (13.47\%).

Since the number of social enterprises types is very unbalanced, as well as the number of employees, further analysis is based on the relative shares of selected categories in the total number of employees in social enterprises (Table 2).

Table 2. Average relative shares of employed categories across types of social enterprises (source: SORS 2014, authors' calculations)

\begin{tabular}{|l|l|l|l|c|c|c|}
\hline & The Young & Elderly & Woman & $\begin{array}{c}\text { Without } \\
\text { professional } \\
\text { qualifications }\end{array}$ & $\begin{array}{c}\text { With } \\
\text { elementary } \\
\text { education }\end{array}$ & $\begin{array}{c}\text { Vulnerable } \\
\text { groups }\end{array}$ \\
\hline $\begin{array}{l}\text { Development } \\
\text { agencies } \\
(\mathrm{N}=31)\end{array}$ & 0.206160 & 0.011500 & 0.5253040 & 0.000000 & 0.015690 & 0.012903 \\
\hline $\begin{array}{l}\text { Foundations } \\
(\mathrm{N}=16)\end{array}$ & 0.261120 & 0.053840 & 0.599272 & 0.000000 & 0.006100 & 0.024252 \\
\hline $\begin{array}{l}\text { Business } \\
\text { incubators } \\
(\mathrm{N}=16)\end{array}$ & 0.068750 & 0.028120 & 0.473958 & 0.000000 & 0.015630 & 0.010417 \\
\hline $\begin{array}{l}\text { Enterprises for } \\
\text { employment } \\
\text { of people } \\
\text { with disabilities } \\
\text { (N = 45) }\end{array}$ & 0.146580 & 0.024240 & 0.429644 & 0.065640 & 0.212250 & 0.650862 \\
\hline $\begin{array}{l}\text { Citizens' } \\
\text { associations } \\
\text { (N = 215) }\end{array}$ & 0.154280 & 0.347000 & 0.565760 & 0.034630 & 0.156660 & 0.178468 \\
\hline $\begin{array}{l}\text { Cooperatives } \\
\text { (N = 649) }\end{array}$ & 0.099150 & 0.062930 & 0.357763 & 0.024200 & 0.106680 & 0.022200 \\
\hline Total (N = 972) & 0.119120 & 0.121610 & 0.418330 & 0.026850 & 0.116560 & 0.085414 \\
\hline
\end{tabular}

Data presented in Table 2 indicate that average shares of youth employees $(26.11 \%)$ and women $(59.92 \%)$ are the highest in foundations, while the average share of elderly is the highest in citizens' associations (34.70\%). Enterprises for employment of people with disabilities employ the highest share of employees without professional qualifications (6.56\%), employees with elementary education (21.23\%) and vulnerable groups (65.09\%).

Since different types of enterprises have distinct approaches when employment of marginalized individuals is concerned, social enterprises in the sample cannot be evaluated based on the employment of a single category of excluded people. Therefore, assessing the contribution of each type of social enterprises to work integration of disadvantaged categories of workers needs to be based on multiple criteria - shares of different marginal categories to whom they offer employment and work integration. 


\section{MCDM model development and results}

The MCDM models are applied in resolving problems that require making a choice out of a number of alternatives or ranking of a finite set of alternatives $A_{i}(i=1,2, \ldots, m)$, based on a number of criteria $C_{j},(j=1,2, \ldots, n)$. The usual form of presentation of these problems is the decision matrix. The coefficients of the decision matrix $x_{i j}$ are called attributes and represent the level at which alternative $A_{i}$ meets the criterion $C_{j}$. The general form of MCDM model presentation is:

$$
\begin{gathered}
C_{1} \\
A_{1} \\
A_{1} \\
A_{2} \\
\vdots \\
A_{m}
\end{gathered}\left[\begin{array}{cccc}
x_{11} & x_{12} & \ldots & x_{1 n} \\
x_{21} & x_{22} & \ldots & x_{2 n} \\
\vdots & \vdots & \vdots & \vdots \\
x_{m 1} & x_{m 2} & \ldots & x_{m n}
\end{array}\right] .
$$

In accordance with the aim of the study, the structure of the proposed model for assessing the contribution of different types of social enterprises to employment of socially excluded groups is presented in Figure 2.

In the proposed model, attributes that define the alternatives present the average relative shares of employees belonging to socially excluded categories in the total number of employees within a particular type of social enterprise. On the other hand, the criteria are defined as the average relative shares of employees belonging to a particular socially excluded group in different types of social enterprises. The average values of relative shares are calculated based on the number of social enterprises within a particular type (observations with missing values have been omitted in the analysis) and presented in Table 2. Higher average relative shares of employees belonging to marginalized groups imply higher level of criteria fulfilment. Therefore, all criteria in the model are maximum type. In order to solve the described problem, an integrated approach of two methods has been applied - entropy for determining weights and TOPSIS method for ranking the alternatives (Kaynak et al. 2017).

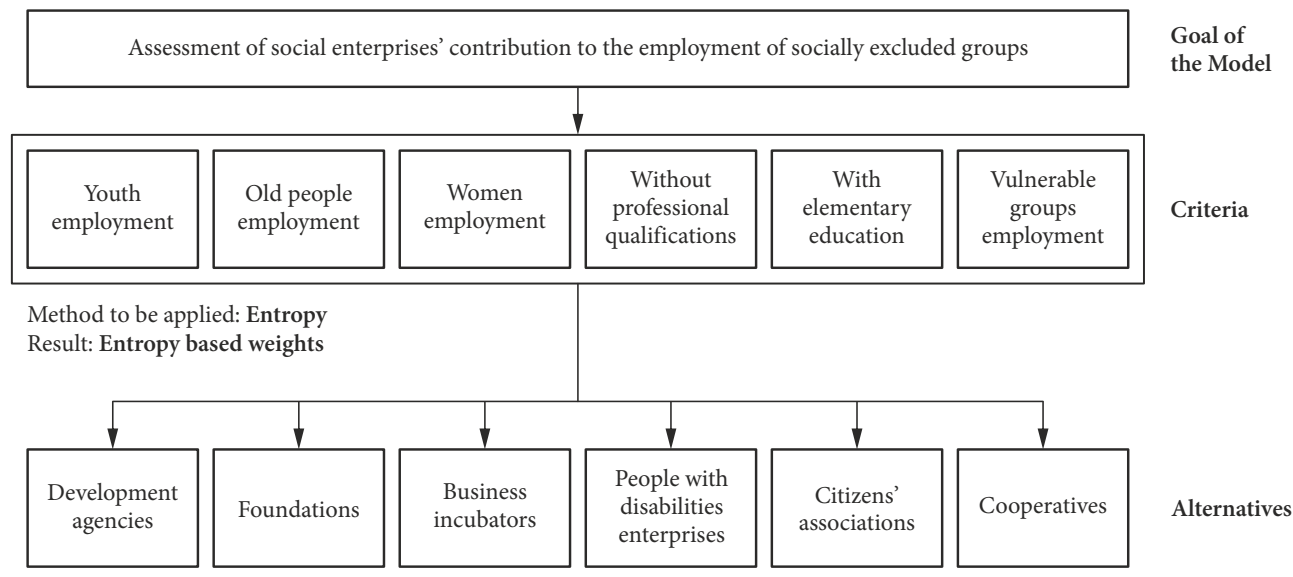

Method to be applied: TOPSIS

Result: Ranking of social enterprises in Serbia according to their contribution to the employment of socially excluded groups

Figure 2. MCDM Model Flowchart - Integrated Approach of Entropy and TOPSIS 


\subsection{Entropy-based weights determination}

The first step of model development is to estimate the relative importance of criteria. The contribution of social enterprises to the employment of socially excluded groups will be assessed on the basis of six $(n=6)$ different criteria that represent average relative shares of employed categories. The relative importance of each criterion is expressed through weights $w_{\mathrm{j}}(j=1,2, \ldots, n)$.

The problem of relative weights determination exists since the formulation of the first multi-criteria analysis methods. During that period several approaches have been proposed to determine weights (Hwang, Yoon 1981; Saaty 1980). Most of them can be classified in two main groups, depending on the information provided for their assessment: (1) subjective and (2) objective approach. Subjective approaches determine weights that reflect subjective judgments, while objective approaches determine weights by making use of mathematical models and they do not consider subjective judgment (Liu 2003).

The most popular subjective approaches are the Analytic Hierarchy Process (Saaty 1977), least squares comparison (Chu et al. 1979), Delphi method (Hwang, Lin 1987), or some recently developed methods based on generalised expert opinion such as KEMIRA (Krylovas et al. 2014, 2016), Step-wise Weight Assessment Ratio Analysis method - SWARA (Keršuliene et al. 2010), Factor Relationship - FARE (Ginevicius 2011), Best Worst Method - BWM (Rezaei 2015), etc. The objective approaches include methods such are LINMAP - Linear Programming Techniques for Multidimensional Analysis of Privileged (Srinivasan, Shocker 1973), various computer-aided mathematical models (Pekelman, Sen 1974), Data Envelopment Analysis (Charnes et al. 1978), the entropy method (Hwang, Yoon 1981; Van Uden, Kwiesielewicz 2003; Chen, Qu 2006), principal component analysis and multi-attribute programming methods (Fan et al. 1999), all statistical methods, etc.

For a specific type of research problem in our paper, considering that subjective preferences of the experts were not available, it is necessary to determine the significance of the criteria on the basis of objective data. The method of choice for weights determination is entropy (Shannon 1948).

Entropy is the measure of the disorder in a system. It can be widely used to evaluate the disorder degree and effectiveness of the information in a system (Shannon 1948). Hence, the weights identified by entropy are also the measurement of the disorder degree of the evaluation system. Entropy weight represents useful information of the evaluation index (Zou et al. 2006). Higher values of entropy weights indicate more useful information of the index. In this study, entropy weight method is used to measure the quantity of the useful information of performance measures and determine their weights.

The algorithm of entropy is given trough following steps:

Step 1. The initial step is constructing the evaluation matrix. Input data for entropy procedure should be collected in the form of decision matrix or so called performance matrix, which means matrix of coefficients that represent performance of each alternative under considering of each evaluation criterion.

Starting with general formulation of MCDM model given with Eq. (1) and considering the fact that our sample includes 1,180 social enterprises in Serbia, the number of alternatives for the purpose of weights determination using entropy will be $m=1,180$. The num- 
ber of alternatives in MCDM model will be revised according to number of types of social enterprises included in research, but since the entropy gives the data about disorder degree of the observed set, thus this part of analysis will deal with data without grouping them in accordance with the type of social enterprise they belong to.

Step 2. The second step of entropy procedure is calculation of normalized matrix described as $P_{m \times n}=\left[\rho_{i j}\right]_{m \times n}$, i.e. calculating the coefficients $\rho_{i j}$. This relation is known as additive normalization and it is given by following:

$$
\rho_{i j}=\frac{x_{i j}}{\sum_{i=1}^{m} x_{i j}}, j=1,2, \ldots, n .
$$

Step 3. The third step is to calculate entropy for each criterion using relation:

$$
H_{j}=-\lambda \sum_{i=1}^{m} \rho_{i j} \ln \rho_{i j}, j=1,2, \ldots, n .
$$

Where $\lambda$ is Boltzman's constant and it can be calculated as $\lambda=1 / \ln m$. The Boltzman constant provides that entropy measures are in the interval from 0 to 1 , i.e. $0 \leq H_{j} \leq 1$.

Step 4. Calculation of the degree of diversification of the information $\overline{H_{j}}$ by following equation:

$$
\overline{H_{j}}=1-H_{j}, j=1,2, \ldots, n \text {. }
$$

Step 5. The entropy based weights $w_{j}$ are calculated as:

where $0 \leq w_{j} \leq 1$ and $\sum_{j=1}^{n} w_{j}=1$.

$$
w_{j}=\frac{\overline{H_{j}}}{\sum_{j=1}^{n} \bar{H}_{j}},
$$

\subsection{TOPSIS method}

In order to determine the level of overall contributions of each type of social enterprise to the employment of socially excluded groups in Serbia, we apply Technique for Order Preference by Similarity to Ideal Solution (TOPSIS). This method was first developed by Hwang and Yoon (1981) to solve a problem in the field of multiple-criteria analysis. It is a method for ranking alternatives, based on the principle of compromise that the chosen alternative should have "the shortest distance from the positive ideal solution" and "the farthest distance from the negative ideal solution" (Hwang, Yoon 1981). In additional research, the same principle of compromise between positive and negative ideal solutions has been suggested also by Zeleny (1982) and Hall (1989).

According to Yoon and Hwang (1995), the algorithm of TOPSIS method includes six successive steps aimed to identify positive-ideal and negative-ideal solutions, as well as measures of separation and similarities to those solutions. The TOPSIS method is presented through following steps (Yoon, Hwang 1995):

Step 1. Calculation of normalized decision matrix $R_{m \times n}=\left[r_{i j}\right]_{m \times n}$ using vector normalization for determination of coefficients $r_{i j}$, where 


$$
r_{i j}=\frac{x_{i j}}{\sqrt{\sum_{i=1}^{m} x_{i j}^{2}}}, i=1,2, \ldots, m, j=1,2, \ldots, n .
$$

Step 2. Calculation of weighted normalized matrix $V_{m \times n}=\left[v_{i j}\right]_{m \times n}$ using relation given as

$$
v_{i j}=w_{j} r_{i j}, i=1,2, \ldots, m, j=1,2, \ldots, n .
$$

Step 3. Determination of positive-ideal $A^{*}$ and negative-ideal $A^{-}$solutions based on given relations where

$$
\begin{aligned}
& A^{*}=\left\{v_{1}^{*}, v_{2}^{*}, \ldots, v_{j}^{*}, \ldots, v_{n}^{*}\right\}=\left\{\left(\max _{i} v_{i j} \mid j \in J_{1}\right),\left(\min _{i} v_{i j} \mid j \in J_{2}\right) \mid i=1,2, \ldots, m\right\} ; \\
& A^{-}=\left\{v_{1}^{-}, v_{2}^{-}, \ldots, v_{j}^{-}, \ldots, v_{n}^{-}\right\}=\left\{\left(\min _{i} v_{i j} \mid j \in J_{1}\right),\left(\max _{i} v_{i j} \mid j \in J_{2}\right) \mid i=1,2, \ldots, m\right\}
\end{aligned}
$$

and $A^{*}$ and $A^{-}$are defined in terms of the weighted normalized values, while $J_{1}$ is the set of benefit-type criteria and $J_{2}$ is the set of cost-type criteria.

Step 4. Calculation of separation from the positive-ideal solution $S_{i}^{*}$ and separation from the negative-ideal solution $S_{i}^{-}$in accordance with relations where

$$
\begin{gathered}
S_{i}^{*}=\sqrt{\sum_{j=1}^{n}\left(v_{i j}-v_{j}^{*}\right)^{2}}, \quad i=1,2, \ldots, m \text { and } \\
S_{i}^{-}=\sqrt{\sum_{j=1}^{n}\left(v_{i j}-v_{j}^{-}\right)^{2}}, \quad i=1,2, \ldots, m .
\end{gathered}
$$

Step 5. Calculation of relative closeness to positive-ideal solution $C_{i}^{*}$ which is given as

$$
C_{i}^{*}=\frac{S_{i}^{-}}{\left(S_{i}^{*}+S_{i}^{-}\right)}, \quad i=1,2, \ldots, m .
$$

The measure of relative closeness to positive-ideal solution is the value between 0 and 1 $\left(0 \leq C_{i}^{*} \leq 1\right)$, where $C_{i}^{*}=0$ if the alternative $A_{i}$ is equal to negative-ideal solution and $C_{i}^{*}=1$ when the alternative $A_{i}$ is equal to positive-ideal solution.

Step 6. Final step of algorithm is determination of rank preference order of alternatives as a rank according to $C_{i}^{*}$ in descending order.

\subsection{Results and discussion}

Based on the general MCDM model given by Eq. (1) and the data presented in Table 2, the decision matrix has been generated and presented in Table 3.

Defined matrix corresponds to the structure of the MCDM model described in Figure 2. The proposed procedure for determining the rank of alternatives in the model is the integrated application of Entropy and TOPSIS method. Based on Entropy measures, weights are determined for all criteria in the model and presented in Table 4. The results show that the most homogenous attributes in the sample refer to criterion $C_{3}$, i.e. the relative number of female employees $\left(\mathrm{H}_{3}\right.$ is equal to 0.915951$)$. This value of entropy indicates that there is no 
significant difference between the various types of social enterprises when it comes to women's participation among employees. It is interesting to note that the share of women among employees is solid in all observed social enterprises and ranges between 36-61\%.

At the same time, entropy measures indicate the largest differences in the attributes related to the fulfilment of the criterion $C_{4}$, i.e. the relative number of employees without professional qualifications and the criterion $C_{2}$, i.e. the relative number of employed old people. Exactly these measures of entropy lead to the conclusion that those are the criteria which should be assigned the highest relative weight because they largely contribute to the aim of the model - assessment of social enterprises' contribution to the employment of socially excluded groups.

According to Eq. (6)-(12), TOPSIS procedure has been conducted and the results are given in Table 5 (detailed calculations are provided in the Appendix). Based on all criteria, the alternative with the highest rank refers to enterprises for employment of people with disabilities $\left(C_{4}^{*}=0.716496\right)$. This means that the enterprises for employment of persons with disabilities are the largest contributors to the employment of socially excluded groups.

Table 3. Decision matrix for MCDM model (source: authors' calculations)

\begin{tabular}{|l|c|c|c|c|c|c|}
\hline & $\begin{array}{c}\text { The } \\
\text { Young }\end{array}$ & Elderly & Woman & $\begin{array}{c}\text { Without } \\
\text { professional } \\
\text { qualifications }\end{array}$ & $\begin{array}{c}\text { With } \\
\text { elementary } \\
\text { education }\end{array}$ & $\begin{array}{c}\text { Vulnerable } \\
\text { groups }\end{array}$ \\
\cline { 2 - 7 } & $C_{1}$ & $C_{2}$ & $C_{3}$ & $C_{4}$ & $C_{5}$ & $C_{6}$ \\
\hline Development agencies & 0.206160 & 0.011500 & 0.525304 & 0.000000 & 0.015690 & 0.012903 \\
\hline Foundations & 0.261120 & 0.053840 & 0.599272 & 0.000000 & 0.006100 & 0.024252 \\
\hline Business incubators & 0.068750 & 0.028120 & 0.473958 & 0.000000 & 0.015630 & 0.010417 \\
\hline $\begin{array}{l}\text { Enterprises } \\
\text { for employment } \\
\text { of people } \\
\text { with disabilities }\end{array}$ & 0.146580 & 0.024240 & 0.429644 & 0.065640 & 0.212250 & 0.650862 \\
\hline Citizens' associations & 0.154280 & 0.347000 & 0.565760 & 0.034630 & 0.156660 & 0.178468 \\
\hline Cooperatives & 0.099150 & 0.062930 & 0.357763 & 0.024200 & 0.106680 & 0.022200 \\
\hline
\end{tabular}

Table 4. Entropy based weights (source: authors' calculation)

\begin{tabular}{|c|c|c|c|c|c|c|}
\hline & $\begin{array}{c}\text { The } \\
\text { Young }\end{array}$ & Elderly & Woman & $\begin{array}{c}\text { Without } \\
\text { professional } \\
\text { qualifications }\end{array}$ & $\begin{array}{c}\text { With } \\
\text { elementary } \\
\text { education }\end{array}$ & $\begin{array}{c}\text { Vulnerable } \\
\text { groups }\end{array}$ \\
\cline { 2 - 7 } & $C_{1}$ & $C_{2}$ & $C_{3}$ & $C_{4}$ & $C_{5}$ & $C_{6}$ \\
\hline $\begin{array}{c}\text { Criterion } \\
\text { type }\end{array}$ & Max & Max & Max & Max & Max & Max \\
\hline$H_{j}$ & 0.779663189 & 0.651506624 & 0.915951383 & 0.567749033 & 0.756889883 & 0.70435107 \\
\hline$\overline{H_{j}}$ & 0.220336811 & 0.348493376 & 0.084048617 & 0.432250967 & 0.243110117 & 0.29564893 \\
\hline$w_{j}$ & 0.135684666 & 0.21460421 & 0.051757618 & 0.266182612 & 0.149708597 & 0.182062298 \\
\hline
\end{tabular}


Table 5. Results of TOPSIS (source: authors' calculation)

\begin{tabular}{|l|c|c|c|c|c|c|}
\hline \multirow{2}{*}{ Type of Social Enterprise } & \multicolumn{2}{|c|}{$\mathrm{Si}^{*}$} & \multicolumn{2}{c|}{$\mathrm{Si}^{-}$} & \multicolumn{2}{c|}{$\mathrm{Ci}^{*}$} \\
\cline { 2 - 7 } & Value & Rank & Value & Rank & Value & Rank \\
\hline Development agencies & 0.135934 & 5 & 0.002127 & 5 & 0.015404 & 5 \\
\hline Foundations & 0.126608 & 4 & 0.004755 & 4 & 0.036196 & 4 \\
\hline Business incubators & 0.135972 & 6 & 0.000160 & 6 & 0.001175 & 6 \\
\hline $\begin{array}{l}\text { Enterprises for employment } \\
\text { of people with disabilities }\end{array}$ & 0.038724 & 2 & 0.097866 & 1 & 0.716496 & 1 \\
\hline Citizens' associations & 0.029864 & 1 & 0.066335 & 2 & 0.689557 & 2 \\
\hline Cooperatives & 0.084973 & 3 & 0.011980 & 3 & 0.123563 & 3 \\
\hline
\end{tabular}

The findings of our study clearly identify the main actors in combating social exclusion within the Serbian social entrepreneurship sector. The importance of these findings is accentuated by taking into account the current socio-economic context related to the issues of unemployment, poverty and social exclusion in Serbia. Namely, after a difficult recent history (wars, international isolation, hyperinflation), followed by severe transitional adjustments, Serbia is now coping with the harsh consequences of global financial crisis. The impact of the crisis has been rather unfavourable - Serbian economy is faced with stagnation and high public debt, resulting in persistent long-term unemployment and extremely low employment rate. Especially worrisome is the youth unemployment and substantial employment in the informal economy. On the other hand, there is a variety of social groups exposed to the risk of poverty and social marginalization (ethnic minorities, people with disabilities, refugees and internally displayed persons, etc.). The number of citizens unable to participate independently in market competition is not only one of the highest in Europe, but also threatens to endanger the functioning of economy. The aggravating social problems in conditions of severe budget constraints and weak economic performance require the engagement of all relevant actors and reconstruction of the government's role. Social enterprises in Serbia seem to have potential to make a distinctive contribution in addressing the problems of poverty and social exclusion, by employing innovative models of employment, service provision and social protection (Kolin 2013).

The data on the employment of analysed marginalized categories indicate that cooperatives employ more than a half of total employees in social entrepreneurship sector, as well as largest shares of young people, women and employees with low education (Table 1). However, when taking into account multiple attributes (in the form of average relative shares of marginalized categories in total employment of cooperatives), we find that cooperatives are not a leading contributor to social inclusion and employment generator in Serbia (ranked $3^{\text {rd }}$ in Table 5). This implies that cooperatives could enhance their potentials regarding this issue, even more because one of the most important objectives of this type of social enterprise is the employment and economic empowerment of their members. Extensive reforms are required concerning this type of social enterprise, as it is burdened by a legacy of public distrust originating from the socialist period that is believed to have corrupted the idea of social economy (Cvejić 2013). To differentiate from the forms of cooperatives inherited from 
the past, innovative types have emerged, focusing on social goals (social cooperatives, women cooperatives, etc.).

On the other hand, enterprises for employment of people with disabilities, although employing only one-fifth of all employees in this sector, largely contribute to the inclusion of marginalized groups and represent major job generator for these social categories. This finding is consistent with the fact that this type of enterprise is specialized in the employment of marginalized groups. It is the only legally recognized form of social enterprise in Serbia, providing vocational training and employment for people with disabilities.

The multi-criteria analysis indicates another important actor in the social entrepreneurship sector - citizens' associations. Employing around 15\% of total number of workers in the sector, they are ranked $2^{\text {nd }}$ regarding the contribution to employment of marginalized groups, since this type of enterprise employs significant shares of most marginalized categories of employees. The specificity of citizen associations in Serbia is that they largely deal with issues related to social exclusion, such as social protection, gender inequality, youth and vulnerable groups, as a response to wide spread poverty and deprivation in the transition period (Vuković 2013). Mostly organized as self-help groups specialized in welfare protection for vulnerable groups, beside job generation for the excluded, they are also oriented to education and humanitarian activities. It was rather expected that the remaining types of social enterprises (foundations, development agencies and business incubators) do not contribute significantly to resolving the problems of social exclusion, since their activities are mainly oriented to other social goals (local development, information sharing, etc.).

Working on employability and work integration of marginalized individuals appears to be a cornerstone in addressing the problems of social exclusion. Although unemployment is one of many determinants of social exclusion, increasing the number of socially and economically independent individuals eases the burden of the whole economy and contributes to the overall economic recovery. Furthermore, assisting economic and social development of disadvantaged communities, social enterprises promote values of solidarity, equity and human dignity, consequently building trust and social capital and strengthening social cohesion. In Serbia, a country with prevailing public attitudes of strong dependence on the state and, paradoxically, a great distrust in it, efforts towards building trust and civic engagement are of particular importance.

\section{Conclusions}

Most of the literature on the potential impact of social enterprises in combating social exclusion suggests that this impact is marginal. Our study is focused on the specific aspect of social exclusion that relates to the inability of individuals to participate in the labor market. The role of social enterprises in work integration of disadvantaged groups is examined in the context of the social integrationist discourse in social exclusion theory, which suggests that labour market participation and paid employment represent the main instrument for fighting exclusion. Our research emphasizes that development of work integration social enterprises could be an efficient tool for fighting social exclusion.

The study contributes to the relatively scarce quantitative research in the field of work integration social enterprises. Using a high-quality national level dataset, we explore the po- 
tentials of different legal forms of social enterprises in Serbia in the employment of a number of socially excluded categories. The data on social enterprises in Serbia show that only a limited number of disadvantaged workers are integrated this way. As different types of enterprises have distinct approaches to work integration of marginalized groups, measuring their impact on social exclusion is evaluated based on the employment of multiple attributes employment of several marginalized categories. Our approach takes into account the shares of different marginalized categories in total number of employees as criteria in the model. The study found that enterprises for employment of persons with disabilities, although they employ around $20 \%$ of the total workforce in the social enterprise sector, contribute the most to work integration, when all categories of disadvantaged workers are considered. Citizens' associations have also appeared as active agents in combating labour market exclusion. Although cooperatives represent the largest share of social enterprises in Serbia and employ more than a half of the total number of employees, when assessed on multiple criteria in the model, their contribution to fighting social exclusion is not fully exploited. These findings introduce new opportunities in creating specific policy measures aimed at developing solutions for work integration within different types of social enterprises. New policy solutions could be aimed at facilitating the development of specific legal forms of social enterprises that are most effective in combating social exclusion.

Alternative approaches for evaluating and ranking social enterprises with respect to their contribution to social inclusion could be considered in future investigations, instead of entropy-based TOPSIS approach that was proposed and employed in our study as the best fitted method in the case of our data. As a possible technique for prioritizing social enterprises considering multiple criteria, VIKOR method could be applied, being a similar procedure also based on aggregating function, representing closeness to the ideal and indicating the compromise solution with the advantage rate. TOPSIS is a suitable method for precise data, but since the data can be customized involving possibilities of potential changes at the labour market, the fuzzy TOPSIS method could be considered, as an alternative ranking methodology.

Further research in this field is needed on several related research questions: creating comparable measures of social enterprise performance in the field of work integration; comparing the impact of social enterprises on social exclusion with the impact produced by enterprises from public and private sector; capturing the impact of social enterprises on other forms of social exclusion and socio-economic inequalities, as well as their contribution to wider community benefits.

\section{Acknowledgements}

The authors are grateful to the Statistical Office of Republic of Serbia for the courtesy of providing database that made this research possible.

\section{Funding}

This work was supported by the Republic of Serbia Ministry of Education, Science and Technological Development. 


\section{Disclosure statement}

Authors do not have any competing financial, professional, or personal interests from other parties.

\section{References}

Aiken, M. 2006. Toward markets or state: tensions and opportunities in the evolutionary path of three UK social enterprises, in M. Nyssens (Ed.). Social enterprise: At the crossroads of market, public policies and civil society. London and New York: Routledge, 259-271.

Aiken, M. 2007. What is the role of social enterprise in finding, creating and maintaining employment for disadvantaged groups? London: Office of the Third Sector.

Alvord, S. H.; Brown, L. D.; Letts, C. W. 2004. Social entrepreneurship and societal transformation: an exploratory study, The Journal of Applied Behavioral Science 40(3): 260-282. https://doi.org/10.1177/0021886304266847

Amin, A. 2009. Extraordinarily ordinary: working in the social economy, Social Enterprise Journal 5(1): 30-39. https://doi.org/10.1108/17508610910956390

Austin, J.; Gutierrez, R.; Ogliastri, E.; Reficco, E. 2006. Effective management of social enterprises: lessons from business and civil society organisations in Iberoamerica. Cambridge, MA: Harvard University Press.

Bacq, S.; Janssen, F. 2011. The multiple faces of social entrepreneurship: a review of definitional issues based on geographical and thematic criteria, Entrepreneurship \& Regional Development 23(5/6): 373-403. https://doi.org/10.1080/08985626.2011.577242

Blackburn, R.; Ram, M. 2006. Fix or fixation? The contributions and limitations of entrepreneurship and small firms to combating social exclusion, Entrepreneurship \& Regional Development 18(1): 73-89. https://doi.org/10.1080/08985620500419566

Borzaga, C.; Loss, M. 2006. Multiple goals and multi-stakeholder management in Italian social enterprises, in M. Nyssens (Ed.). Social enterprise: at the crossroads of market, public policies and civil society. London and New York: Routledge, 169-194.

Burchardt, T.; Le Grand, J.; Piachaud, D. 2002. Degrees of exclusion: developing a dynamic, multidimensional measure, in J. Hills, J. Le Grand, D. Piachaud (Eds.). Understanding social exclusion. Oxford: Oxford University Press.

Byrne, D. 2005. Social exclusion. Maidenhead, UK: Open University Press.

Charnes, A.; Cooper, W.W.; Rhodes, E. 1978. Measuring the efficiency of decision making units, European Journal of Operational Research 12(6): 429-444. https://doi.org/10.1016/0377-2217(78)90138-8

Chen, Y.; Qu, L. 2006. Evaluating the selection of logistics centre location using Fuzzy MCA Model based on entropy weight, in The IEEE Proceedings of 6th World Congress on Intelligent Control and Automation 2: 7128-7132.

Choi, N.; Majumdar, S. 2014. Social entrepreneurship as an essentially contested concept: opening a new avenue for systematic future research, Journal of Business Venturing 29(3): 363-376. https://doi.org/10.1016/j.jbusvent.2013.05.001

Chu, A. T. W.; Kalaba, R. E.; Spingarn, K. 1979. A Comparison of two methods for determining the weights of belonging to Fuzzy Sets, Journal of Optimization Theory and Applications 27(4): 531-538. https://doi.org/10.1007/BF00933438

Cochrane, A. 2003. The new urban policy: towards empowerment or incorporation? The practice of urban policy, in R. Imrie, M. Waco (Eds.). Urban renaissance? New labour, community and urban policy. Bristol: The Policy Press. https://doi.org/10.2307/j.ctt1t898kc.17 
Cvejić, S. 2013. Public Policies as a Framework for Development of Social Entrepreneurship in Serbia, in S. Cvejić (Ed.). Cooperatives and social enterprises in Europe and in transitional contexts. Belgrade: The Institute for Sociological Research, 48-61.

Dacin, P.; Dacin, M.; Matear, M. 2010. Social entrepreneurship: why we don't need a new theory and how we move forward from here, Academy of Management Perspectives 24(3): 37-57. https://doi.org/10.5465/AMP.2010.52842950

Davister, C.; Defourny, J.; Gre'goire, O. 2004. Work integration social enterprises in the European Union: an overview of existing models. EMES working papers 04/04. Lie'ge: EMES European Research Network.

Dees, J. G. 1998. The meaning of social entrepreneurship [online], [cited 25 September 2016]. Available from Internet: http://www.redalmarza.cl/ing/pdf/TheMeaningofsocialEntrepreneurship.pdf.

Dees, J.; Anderson, B. 2006. Framing a theory of social entrepreneurship: building on two schools of practice and thought, in Research on social entrepreneurship, ARNOVA occasional paper series 1(3): $39-66$.

Defourny, J.; Nyssens, M. 2006. Defining social enterprise, in M. Nyssens (Ed.). Social enterprise: at the crossroads of markets, public policies and civil society. London, New York: Routledge, 3-26.

Defourny, J.; Nyssens, M. 2008. Social enterprise in Europe: recent trends and developments, Social Enterprise Journal 4(3): 202-228. https://doi.org/10.1108/17508610810922703

Defourny, J.; Nyssens, M. 2010. Social enterprise in Europe: at the crossroads of market, public policies and third sector, Policy and Society 29(3): 231-242. https://doi.org/10.1016/j.polsoc.2010.07.002

Defourny, J.; Nyssens, M. 2012. The EMES approach of Social enterprise in a comparative perspective, in EMES Working papers 12/03.

Department of Trade and Industry. 2002. Social enterprise: a strategy for success. DTI: London.

Doherty, B.; Haugh, H.; Fergus L. 2014. Social enterprises as hybrid organizations: a review and research agenda, International Journal of Management Reviews 16: 417-436. https://doi.org/10.1111/ijmr.12028

Dussart, C.; Grosjean, P.; Hamende, V.; Toussaint, V. 2003. L'Economie Sociale d'Insertion. Rapport Final, Ciriec.

Evers, A. 2001. The significance of social capital in the multiple goal and resource structure of social enterprises, in C. Borzaga, J. Defourny (Eds.). The emergence of social enterprise. London, New York: Routledge, 296-311.

European Commission. 2011. Social Business Initiative - Creating a favorable climate for social enterprises, key stakeholders in the social economy and innovation. COM (2011) 682 final. European Commission, Brussels.

EU SILC - EU Statistics on Income and Living Conditions [online]. 2016 [cited 15 January 2017]. Available from Internet: http://ec.europa.eu/eurostat/web/income-and-living-conditions/data/database

Fan, Z.; Ma, J.; Tian, P. 1999. A subjective and objective integrated approach for the determination of attribute weights, European Journal of Operational Research 112(2): 397-404. https://doi.org/10.1016/S0377-2217(98)00141-6

Giddens, A. 1998. The third way; the renewal of social democracy. Maiden Mass: Polity Press.

Gilbert, N. 2002. Transformation of the Welfare State. The silent surrender of public responsibility. Oxford: Oxford University Press. https://doi.org/10.1093/0195140745.001.0001

Ginevicius, R. 2011. A new determining method for the criteria weights in multi-criteria evaluation, International Journal of Information Technology \& Decision Making 10(6): 1067-1095.

https://doi.org/10.1142/S0219622011004713

Hall, A. D. 1989. Matasystems methodology: a new synthesis and unification. Oxford: Pergamon Press. 
Haugh, H.; Kitson, M. 2007. The third way and the third sector: New Labour's economic policy and the social economy, Cambridge Journal of Economics 31: 973-994. https://doi.org/10.1093/cje/bem027

Hill, T.; Kothari, T.; Shea, M. 2010. Patterns of meaning in the social entrepreneurship literature: a research platform, Journal of Social Entrepreneurship 1(1): 5-31. https://doi.org/10.1080/19420670903442079

Hoogendoorn, B.; Pennings, E.; Thurik, R. 2010. What do we know about social entrepreneurship: an analysis of empirical research, International Review of Entrepreneurship 8(2): 71-112.

Hulgård, L.; Bisballe, T. 2008. Work integration social enterprises in Denmark [online], [cited 25 September 2016]. Available from Internet: http://emes.net/content/uploads/publications/PERSE_WP_0408_DK.pdf

Hudson, R. 2005. The social economy beyond the local? developmental possibilities, problems and policy considerations, Durham research online [online], [cited 25 September 2016]. Available from Internet: http://dro.dur.ac.uk/19/1/Hudson_social.pdf?DDD14

Hwang, C. L.; Yoon, K. 1981. Multiple attribute decision making: methods and applications. Berlin: Springer-Verlag. https://doi.org/10.1007/978-3-642-48318-9

Hwang, C. L.; Lin, M. J. 1987. Group decision making under multiple criteria: methods and applications. Berlin: Springer-Verlag. https://doi.org/10.1007/978-3-642-61580-1

Iwacewicz-Orlowska, A. 2016. Diversity of poverty in the chosen European Union countries within the period 2006-2014, Proceedings of Rijeka Faculty of Economics: Journal of Economics and Business 34(2): 481-503.

Jati, H. 2012. Comparison of university webometrics ranking using multicriteria decision analysis: TOPSIS and VIKOR method. Paris: World Academy of Science, Engineering and Technology.

Jee, D. H.; Kang, J. K. 2000. A method for optimal material selection aided with decision making theory, Materials and Design 21(3): 199-206. https://doi.org/10.1016/S0261-3069(99)00066-7

Kaynak, S.; Altuntas, S.; Dereli, T. 2017. Comparing the innovation performance of EU candidate countries: an entropy-based TOPSIS approach, Economic Research 30(1): 31-54. https://doi.org/10.1080/1331677X.2016.1265895

Kerlin, J. 2006. Social enterprise in the United States and Europe: understanding and learning from the differences, Voluntas 17(3): 247-263. https://doi.org/10.1007/s11266-006-9016-2

Keršuliene, V.; Zavadskas, E. K.; Turskis, Z. 2010. Selection of rational dispute resolution method by applying new stepwise weight assessment ratio analysis (SWARA), Journal of Business Economics and Management 11(2): 243-258. https://doi.org/10.3846/jbem.2010.12

Kolin, M. 2013. Main types of social enterprises in Serbia, in S. Cvejić (Ed.). Cooperatives and social enterprises in Europe and in transitional contexts. Belgrade: The Institute for Sociological Research, 79-86.

Koller, V.; Davidsson, P. 2008. Social exclusion as conceptual and grammatical metaphor: a cross-genre study of British policy-making, Discourse \& Society 19(3): 307-331. https://doi.org/10.1177/0957926508088963

Krylovas, A.; Zavadskas, E. K.; Kosareva, N.; Dadelo S. 2014. New KEMIRA Method for determining criteria priority and weights in solving MCDM problem, International Journal of Information Technology \& Decision Making 13(6): 1119-1133. https://doi.org/10.1142/S0219622014500825

Krylovas, A.; Zavadskas, E. K.; Kosareva, N. 2016. Multiple criteria decision-making KEMIRA-M method for solution of location alternatives, Economic Research-Ekonomska Istraživanja 29(1): 50-65. https://doi.org/10.1080/1331677X.2016.1152560

Kummitha, R. K. R. 2016. Social entrepreneurship as a tool to remedy social exclusion: a win-win scenario?, South Asia Research 36(1): 61-79. https://doi.org/10.1177/0262728015615485

Lane, M. D.; Casile, M. 2011. Angels on the head of a pin: The SAC framework for performance measurement in social entrepreneurship ventures, Social Enterprise Journal 7(3): 238-258.

https://doi.org/10.1108/17508611111182395 
Lenoir, R. 1974. Les Exclus: un Français sur dix. Paris: Seuil.

Lee, M.; Battilana, J.; Wang, T. 2014. Building an infrastructure for empirical research on social enterprise: challenges and opportunities, in J. Short (Ed.). Social Entrepreneurship and Research Methods (Research Methodology in Strategy and Management, Volume 9). Emerald Group Publishing Limited, 241-264.

Levander, U. 2009. Social exclusion - an analytical aspect of the social enterprise, in $2^{\text {nd }} E M E S$ Conference on Social Enterprise, 1-4 July 2009, Trento, Italy.

Levitas, R. 2004. Let's hear it for Humpty: social exclusion, the third way and cultural capital, Cultural Trends 13(2): 41-56. https://doi.org/10.1080/0954896042000267143

Lister, R. 2004. Poverty. Cambridge: Polity Press.

Liu, C. C. 2003. Simulating weights restrictions in data envelopment analysis by the subjective and objective integrated approach, Web Journal of Chinese Management Review 6(1): 68-78.

Mair, J.; Martí, I. 2006. Social entrepreneurship research: a source of explanation, prediction and delight, Journal of World Business 41(1): 36-44. https://doi.org/10.1016/j.jwb.2005.09.002

Maree, M. 2005. Les effects collectifs de l'insertion. Centre d'Economie Sociale.

McLoughlin, J.; Kaminski, J.; Sodagar, B., Khan, S.; Harris, R.; Arnaudo, G.; Mc Brearty, S. 2009. A strategic approach to social impact measurement of social capital enterprises: the SIMPLE methodology, Social Enterprise Journal 5(2): 154-178. https://doi.org/10.1108/17508610910981734

McNeill, F.; Weaver, B. 2010. Changing lives? Desistance research and offender management, SCCJR Project Report; No.03/2010. The Scottish Centre for Crime and Justice Research.

Nicholls, A. 2005. Measuring impact in social entrepreneurship: new accountabilities to stakeholders and investors?, in ESRC Research Seminar, April 2005, Local Government Research Unit, London.

Nicholls, A. (Ed.). 2006. Social entrepreneurship: new models of sustainable social change. Oxford: Oxford University Press.

Opricovic, S.; Tzeng, G. H. 2004. Compromise solution by MCDM methods: a comparative analysis of VIKOR and TOPSIS, European Journal of Operational Research 156(2): 445-455. https://doi.org/10.1016/S0377-2217(03)00020-1

Parkan, C.; Wu, M. L. 1997. On the equivalence of operational performance measurement and multiple attribute decision making, International Journal of Production Research 35(11): 2963-2988. https://doi.org/10.1080/002075497194246

Pekelman, D.; Sen, S. K. 1974. Mathematical programming models for the determination of attribute weights, Management Science 20(7): 1217-1229. https://doi.org/10.1287/mnsc.20.8.1217

Peredo, A. M.; McLean, M. 2006. Social entrepreneurship: a critical review of the concept, Journal of World Business 41(1): 56-65. https://doi.org/10.1016/j.jwb.2005.10.007

Perista, H.; Nogueira, S. 2006. Profiles and trajectories of participants in European work integration social enterprises, in M. Nyssens (Ed.). Social enterprise: at the crossroads of market, public policies and civil society. London and New York: Routledge, 195-205.

Putnam, R. 1993. Making democracy work: civic traditions in modern Italy. Princeton: Princeton University Press.

Radović-Marković, M. 2016. Empowering employment of women and marginalized people through entrepreneurship education in Serbia, Journal of Women's Entrepreneurship and Education 1-2: 3-17.

Rezaei, J. 2015. Best-worst multi-criteria decision-making method, Omega 53: 49-57. https://doi.org/10.1016/j.omega.2014.11.009

Roy, B. 1968. Clessement et choix en presence de criteres multiples, RIRO 8: 57-75. https://doi.org/10.1051/ro/196802V100571

Saaty, T. L. 1977. A scaling method for priorities in hierarchical structures, Journal of Mathematical Psychology 15: 234-281. https://doi.org/10.1016/0022-2496(77)90033-5 
Saaty, T. L. 1980. Multicriteria decision making: the analytic hierarchy process. New York, NY: McGrawHill.

Seyfang, G. 2004. Working outside the box: community currencies, time banks and social inclusion, Journal of Social Policy 33(1): 49-71. https://doi.org/10.1017/S0047279403007232

Shannon, C. E. 1948. A mathematical theory of communications, The Bell System Technical Journal 27: 379-423. https://doi.org/10.1002/j.1538-7305.1948.tb01338.x

Shih, H. S.; Syur, H. J.; Lee, E. S. 2007. An extension of TOPSIS for group decision making, Mathematical and Computer Modeling 45: 801-813. https://doi.org/10.1016/j.mcm.2006.03.023

Short, J. C.; Moss, T. W.; Lumpkin, G. T. 2009. Research in social entrepreneurship: past contributions and future opportunities, Strategic Entrepreneurship Journal 3(2): 161-194. https://doi.org/10.1002/sej.69

Silver, H. 1994. Social exclusion and social solidarity: three paradigms, International Labour Review 133(5-6): 531-578.

Silver, H. 2010. Social inclusion policies: lessons for Australia, Australian Journal of Social Issues 45(2): 183-211. https://doi.org/10.1002/j.1839-4655.2010.tb00174.x

Simon, M. 1998. Lentreprise d'insertion: à l’épreuve de la réalité économique. Bruxelles: Fondation Roi Baudouin.

Smallbone, D.; Evans, M.; Ekanem, I.; Butters, S. 2001. Researching social enterprise. Report for the Small Business Service, London: SBS.

Srinivasan, V.; Shocker, A. D. 1973. Estimating the weights for multiple attributes in a composite criterion using pairwise judgments, Psychonometrica 38(4): 473-493. https://doi.org/10.1007/BF02291490

Spear, R.; Bidet, E. 2005. Social enterprise for work integration in 12 European countries: a descriptive analysis, Annals of Public and Cooperative Economics 76(2): 195-231. https://doi.org/10.1111/j.1370-4788.2005.00276.x

SORS - Statistical Office of the Republic of Serbia 2014. Economic impact of social enterprises [online], [cited 20 December 2015] (database). Available from Internet: http://www.stat.gov.rs/WebSite/Public/PageView.aspx?pKey=520

SORS - Statistical Office of the Republic of Serbia, SeConS and Group 484. 2014a. Economic Impact of Social Enterprises in the Republic of Serbia [online], [cited 20 December 2015]. Final report on social enterprises. Statistical Office of the Republic of Serbia, Belgrade. Available from Internet: http://ec.europa.eu/growth/tools-databases/newsroom/cf/itemdetail.cfm?item_id=8650\&lang=en

Toner, A.; Lyne, I.; Ryan, P. 2008. Reaching the promised land: can social enterprise reduce social exclusion and empower communities?, Education, Knowledge and Economy 2(1): 1-14. https://doi.org/10.1080/17496890801953901

Teasdale, S. 2008. Can social enterprise address disadvantage? Evidence from an inner city community, TSRC Working paper no 3.

Van Uden, E.; Kwiesielewicz, M. 2003. Evaluating attribute significance in AHP using Shannon Entropy, in ISAHP 2003, 7-9 August 2003, Bali, Indonesia.

Vidal, I. 2005. Social enterprise and social inclusion: social enterprises in the sphere of work integration, International Journal of Public Administration 28(9-10): 807-825. https://doi.org/10.1081/PAD-200067347

Vuković, D. 2013. Social Economy, Civil Society and the Serbian Welfare System, in S. Cvejić (Ed.). Cooperatives and social enterprises in Europe and in transitional contexts. Belgrade: The Institute for Sociological Research, 62-78.

Weerawardena, J.; Mort, G. 2006. Investigating social entrepreneurship: a multidimensional model, Journal of World Business 41(1): 21-35. https://doi.org/10.1016/j.jwb.2005.09.001 
Yoon, K. P.; Hwang, C. L. 1995. Multiple attribute decision making: an introduction. Sage University Paper series: Quantitative Applications in the Social Sciences, 07-104. Thousand Oaks, CA: Sage. https://doi.org/10.4135/9781412985161

Yong, D. 2006. Plant location selection based on fuzzy TOPSIS, International Journal of Advanced Manufacturing Technology 28(7-8): 839-844. https://doi.org/10.1007/s00170-004-2436-5

Zanakis, S. H.; Solomon, A.; Wishart, N.; Dublish, S. 1998. Multi-attribute decision making: a simulation comparison of select methods, European Journal of Operational Research 107(3): 507-529. https://doi.org/10.1016/S0377-2217(97)00147-1

Zeleny, M. 1982. Multiple criteria decision making. McGraw-Hill, New York.

Zou, Z. H.; Yun, Y.; Sun, J. N. 2006. Entropy method for determination of weight of evaluating in fuzzy synthetic evaluation for water quality assessment indicators, Journal of Environmental Science 18: 1020-1023. https://doi.org/10.1016/S1001-0742(06)60032-6 


\section{APPENDIX}

Table A1. Normalized decision matrix

\begin{tabular}{|l|c|c|c|c|c|c|}
\hline & $\begin{array}{c}\text { The } \\
\text { Young }\end{array}$ & Elderly & Woman & $\begin{array}{c}\text { Without } \\
\text { professional } \\
\text { qualifications }\end{array}$ & $\begin{array}{c}\text { With } \\
\text { elementary } \\
\text { education }\end{array}$ & $\begin{array}{c}\text { Vulnerable } \\
\text { groups }\end{array}$ \\
\hline Development agencies & 0.499233 & 0.032046 & 0.430003 & 0.000000 & 0.054959 & 0.019090 \\
\hline Foundations & 0.632322 & 0.150032 & 0.490551 & 0.000000 & 0.021367 & 0.035882 \\
\hline Business incubators & 0.166483 & 0.078360 & 0.387972 & 0.000000 & 0.054749 & 0.015412 \\
\hline $\begin{array}{l}\text { Enterprises for } \\
\text { employment of people } \\
\text { with disabilities }\end{array}$ & 0.354955 & 0.067548 & 0.351697 & 0.840883 & 0.743476 & 0.962969 \\
\hline Citizens' associations & 0.373601 & 0.966958 & 0.463119 & 0.443629 & 0.548754 & 0.264049 \\
\hline Cooperatives & 0.240099 & 0.175362 & 0.292857 & 0.310015 & 0.373682 & 0.032846 \\
\hline
\end{tabular}

Source: Authors' calculation according to TOPSIS algorithm.

Table A2. Weighted normalized decision matrix

\begin{tabular}{|l|c|c|c|c|c|c|}
\hline & $\begin{array}{c}\text { The } \\
\text { Young }\end{array}$ & Elderly & Woman & $\begin{array}{c}\text { Without } \\
\text { professional } \\
\text { qualifications }\end{array}$ & $\begin{array}{c}\text { With } \\
\text { elementary } \\
\text { education }\end{array}$ & $\begin{array}{c}\text { Vulnerable } \\
\text { groups }\end{array}$ \\
\hline Development agencies & 0.067738 & 0.006877 & 0.022256 & 0.000000 & 0.010006 & 0.003476 \\
\hline Foundations & 0.085796 & 0.032197 & 0.025390 & 0.000000 & 0.003890 & 0.006533 \\
\hline Business incubators & 0.022589 & 0.016816 & 0.020080 & 0.000000 & 0.009968 & 0.002806 \\
\hline $\begin{array}{l}\text { Enterprises for } \\
\text { employment of people } \\
\text { with disabilities }\end{array}$ & 0.048162 & 0.014496 & 0.018203 & 0.223828 & 0.135359 & 0.175320 \\
\hline Citizens' associations & 0.050692 & 0.207513 & 0.023970 & 0.118086 & 0.099907 & 0.048073 \\
\hline Cooperatives & 0.032578 & 0.037633 & 0.015158 & 0.082521 & 0.068033 & 0.005980 \\
\hline
\end{tabular}

Source: Authors' calculation according to TOPSIS algorithm.

Table A3. Positive and negative ideal solutions

\begin{tabular}{|l|c|c|c|c|c|c|}
\hline & $\begin{array}{c}\text { The } \\
\text { Young }\end{array}$ & Elderly & Woman & $\begin{array}{c}\text { Without } \\
\text { professional } \\
\text { qualifications }\end{array}$ & $\begin{array}{c}\text { With } \\
\text { elementary } \\
\text { education }\end{array}$ & $\begin{array}{c}\text { Vulnerable } \\
\text { groups }\end{array}$ \\
\hline Positive Ideal Solution & 0.085796 & 0.207513 & 0.025390 & 0.223828 & 0.135359 & 0.175320 \\
\hline Negative Ideal Solution & 0.022589 & 0.006877 & 0.015158 & 0.000000 & 0.003890 & 0.002806 \\
\hline
\end{tabular}

Source: Authors' calculation according to TOPSIS algorithm. 